\title{
Determined Factors of Human Capital Valuation: An Empirical Study in Higher Education Institution
}

\author{
Tubandrijah Herawati ${ }^{1 *}$, Putu Prima Wulandari ${ }^{2}$, Didied Affandy ${ }^{3}$ \\ \{herawati@ub.ac.id ${ }^{1}$, ptprimawulan@gmail.com ${ }^{2}$, affandy@ub.ac.id ${ }^{3}$ \} \\ Brawijaya University, Indonesia ${ }^{1,2,3}$
}

\begin{abstract}
During disrupted economy era with rapid technological development, the role of human capital is often overlooked, especially when information and communication technologies (ITCs) have replaced some of the human functions. Even some experts argued that human capital is an asset of the organization, the contradict of human accounting treatments remains an interested issue especially when human valuation becomes one of the key drivers of the growth of organization such as in higher education institution (HEI). Using analytical hierarchy process (AHP), this study examines whether the human resource development expenses may be accounted as the key driver in a HEI development and determines which human-development activities that continually may contribute to the HEI value. The result shows that the cost of professional or competence development is as the most important activities in the human capital valuation process. This study, therefore, is supporting the previous studies in which such attributes as life experience, knowledge, innovation, motivation are the critical human capital dimension to contribute to the value of institutions.
\end{abstract}

Keywords: human capital valuation, analytical hierarchical process, higher education institution

\section{Introduction}

During the digital economy era with the rapid development of information and communication technology (ICT), the role of human capital is often overlooked, and in some organizations, ICT almost replaced human function in the organization [4]. However, for public institution specifically, human capital is remaining a valuable resource that may affect organizational performance. Even some intellectual and knowledge intensive institutions, human capital is one of the key determined factors of organization sustainability.

Human capital's quality plays a vital role in carrying out the company's operational activities; utilizing other resources within the company, and executing the business strategy [15]. Thus, the loss of professional human resources becomes a significant shortfall for the organization, since it will dispose of all of the costs that have been expended for them. Another disadvantage is the loss of opportunities to utilize human resources to increase profits [2].

Unfortunately, even though many experts claim that human resources are the assets of organizations, in reality, human resource development is merely recorded as an expense in financial statements deemed to be no value activities [14]. Besides, the accounting problems for human capital values differ significantly from the concept of historical cost issue. On a broader scale, the measurement of human capital merely based on historical costing process to the company [27]. The problem occurs when the organization has to face future valuation where the value of human resources relies on forecasts and uncertainties. In the effort of bridging this problem, recent scholars have proposed several measurements [14].

Like other resources, human capital would create a value to the organization since they can provide services in the future. From that perspective, this study aims to the importance to hire a concept of human resource accounting (HRA), a process of utilizing human services to achieve the mission of the organization [26]. Recognition of human capital has to congruence with the economic concept as well as the concept of accounting [4;11]. Since the human capital is considered as the driving force of an organization, understanding human resources as the motor of the organization must be followed up by the weighting or recognition of human resources as a component in the financial statements that can also produce other components $[1 ; 23]$. By doing so, this study focus on the analytical hierarchy process (AHP) as a reliable tool for measuring a valuation of human capital better than other tools that currently available [28; 29]. 
In the meantime, without adequate human capital or resources, the organization's activities will not run well accordingly. There is no exception to higher education institution (HEI) that provides educational services where the role of lecturers, professors, and educational personnel is believed as the determinant of quality and organizational performance. However, the cost of developing human resources in higher education institution, is often a non-value-added activity for individuals as well as for institutional development. Therefore, it is necessary to identify and measure data on human resources and relay this information to interested parties to clarify the added value of human resource development activities. Also, to enrich the development of human capital valuation concept, this study aims to fill the void of measurement in human capital in general and AHP in particular.

\section{Literature Review}

\subsection{Human Resources Accounting (HRA)}

Human resource accounting (HRA) is a firm recognition of the notion that human beings are valuable organizational resource and an integral part of the mix of resources. On a broader scale, HRA will greatly assist human resource management in decision making [3]. The domain of accounting discusses human resources as company asset is HRA $[15 ; 22 ; 26]$. This contradicts the traditional accounting that treats human resources as a burden and reduces profits [7]. Sarwoko [29] emphasized that the difference between HRA and non-accounting of human resources is fundamental. Within the scope of HRA, human resources are included in assets and reported in financial statements.

Human resource accounting (HRA) is a process of identifying and measuring data on human resources and communicating this information to interested parties [5]. The purpose of this concept is to improve the quality of financial decisions made by stakeholders by introducing human capital variables to the traditional scope of management decision making. The existence of HRA as a measuring tool for decision makers of human resources is necessary for the development of business today [19; 24]. Furman $\&$ Mary [13] argue that the concept of human resource value stems from a general economic value theory whereby all human resources have value because they can provide benefits in the future. From this opinion, the value of individual human assets to the firm can be defined as the present value of future services that individuals provide when they continue working for the enterprise. Mayo [21] argues that it is impossible to insert human values into the company's balance sheet unlike any other physical asset of factories and equipment.

The term of human capital asset can be used to describe the value of an asset from a company's human resources. Humans have a human capital dimension which is the collective number of attributes, life experiences, knowledge, innovation, energy, and enthusiasm that a person chooses to work in their place of work $[4 ; 15]$.

\subsection{The Concept of Human Resource Expenditures}

Human resources expenditure comes from the historical cost concepts that represent the costs incurred to obtain or replace employees. The human resources expenses have been treated and asset component, or it can also comprise the outlay cost and opportunity costs $[9 ; 11 ; 13]$. Besides, conventional accounting concept of acquisition cost has relevance in HRA [19; 29].

\subsection{Human Capital Measurement and Valuation}

Human capital represents the amount of person's knowledge, skill, and ability in organization, and also a source of innovation and modernization strategic [16]. Human capital is an asset that is important to organization, because with their creativity and innovation will help the organization to solve problem and lead the using of another asset in organization. Human capital is one of intellectual capital (IC) components and the most significant element of IC, because a company can accomplish nothing-including innovation - without it [18]. Human capital is precursor to structural and relational capital and influences on innovation performance via these IC components [18]. This means that human capital is the crucial component for the other capital and becomes competitive advantage - as its influence innovation performance in organization. Furthermore, intellectual capital has an impact on creating value and increasing the performance of organization, especially in financial performance [25]. IC development can be interpreted as a mission for university as they are created and funded with the purpose of building the workforce of tomorrow, stimulating organizational and technological innovation, and enhancing the 
network of relationships that cross-fertilize industrial and academic expertise [30]. This can be interpreted that developing human capital can increase intellectual capital and furthermore it also can increase organization performance. In higher education institution context, human capital especially promotion and number of researcher become highest priority in the intellectual capital is for growth and organizations development [16].

Human capital dimension is the collective number of attributes, life experiences, knowledge, innovation, energy, and enthusiasm of a person choosing to work in their place of work [7; 11; 17]. Human capital refers to a combination of factors that include knowledge, skills and technical skills, personal characteristics such as intelligence, energy, attitude, reliability, commitment, learning ability, including talent, imagination and creativity, to share information, participate in teams and focus on achieving organizational goals [4; 23] and owned by each and the ability of the workforce [1]. As mandated by Law No. 14/2005 on Teachers and Lecturers [32] lecturers are considered as professional educators and scientists with the primary task of transforming, developing and disseminating science, technology and the arts through education, research and community service. Meanwhile, professionals are declared as a person undertakes work or activities and become a source of income that requires expertise, skill, or skill that meets certain quality or norm standards and requires professional education. The competence of educators, especially lecturers, is defined as a set of knowledge, skills, and behaviors that must be acquired, lived, mastered and realized by the lecturers in carrying out their professional duties. These competencies include pedagogic competence, personality competence, social competence, and professional competence.

Lecturer competence determines the quality of the implementation of "Tridharma Perguruan Tinggi" as shown in the professional activities of lecturers. According to the Law No. 12/2012 on Higher Education Institution [31] there are three obligations of Higher Education Institution: (1) Research defines as an activity that carried out according to systematic scientific rules and methods for obtain information, data, and explanation which relating to understanding and / or testing a branch of science and technology; (2) Public Service defines as academicians activity who use science and Technology to advance community welfare and educate people; and (3) Learning defines as the process of student interaction with lecturers and learning resources at learning environment. This is means that lecturer must do research, public service, and learning as their duties in Higher Education Institution. These duties require lecturer to have pedagogical, professionalism, personality and social competence to perform those mandatory tasks.

There are two methods of human capital measurement, which are monetary and non-monetary measurement method. Monetary measurements emphasize the unit of value of money in measuring human values while nonmonetary measurement emphasizes the form of perception or achievement value measured from the organizational structure $[19 ; 29]$. Monetary measurements is historical method/acquisition cost that consists of valuation of all costs associated with new recruitment, selection, payroll and education / training, and further amortizing those costs over the expected useful life of the asset, recognizing loss in the case of an asset or by enhancing the value of the asset because any additional expense is expected to enlarge the potential assets $[2 ; 17 ; 19 ; 29]$. Limitations that occur in using these measures are the economic value of an asset in the form of human may not be required by its historical value. Any appreciation is likely to be subjective and costs related to human resource management may differ from one individual to another within a company. While non-monetary measure is used by economists to analyze the effectiveness of human organizations through a list of questions based on theoretical models, the outcomes serve as a non-monetary measure of human assets, as they illustrate human perceptions of workplace mood $[15 ; 19 ; 29]$.

The valuation concept of human capital can or may be derived from general economic theory, because of their ability to provide future economic values. In line with economy assumption, the value of individuals is usually defined as the cash value of services rendered to the organization. Sarwoko study [29] argues how to determine the value of a human asset as follows: "To measure and disclose the value of human resources required a theoretical framework or human resource value to explain the types and factors that determine the human value for a company or organization."

The size of a person's price is the value that is expected to be realized $[10 ; 12 ; 22]$ The size of the value comes from the interaction of two variables: (1) The expected conditional value of the individual; and (2) The individual possibility will retain its membership in an organization. This conditional value is 
the value of a person's services while in a company and the combination of multidimensional variables consisting of work productivity, transferability, and ability for competency development. [2] explains that human assets are the creators of value for the company and there are individual multiplier assets designed to reflect the relevant factors that can make the individual value. Individual asset multiplier consists of: (1) Specific knowledge, skills and experience; (2) Individual and behavioral abilities; (3) Contribution of value to stakeholders; (4) Have potential to grow and have a higher contribution rate; (5) Personal productivity in relation to value creation to stakeholders; (6) Achieving goals that in line with company values.

\section{Research Methods}

The study used a quantitative approach to determine the usefulness of analytical hierarchy process (AHP) on measuring human resource value in an organization. In general, the steps in this research are carried out through the following stages: (1) conducting literature review of journals, books, and articles on the internet related to AHP; (2) preparing questionnaire; (3) distributing questionnaires to respondents; (4) processing data; (5) determining criteria and alternatives to be used in ranking process; (6) analyzing data using basic principles of AHP; and (7) conclusion from the results of the study.

Analytical hierarchy process (AHP)

AHP method is one of models for decision making that help the framework of human thinking [17; $28 ; 29]$. AHP method is a numerical scoring process to rank each alternative based on how the alternative should be matched against decision-making criteria. The AHP method is conducted by modeling the problem in stages consisting of criteria and alternatives $[17 ; 28]$. A hierarchy is needed in using AHP to define the problem and pairwise comparison to determine the relationship within the structure. The hierarchical structure is depicted in a tree diagram that contains the goal, criteria, sub-criteria, and alternatives. To make decisions in an organized way and to generate a priority this study describes the decision with the following steps: (1) determine the problem and determine the type of information about the problem sought; (2) developing a hierarchical structure of decisions with the top level is the purpose of the decision which is a broad perspective, then in the middle level there are criteria that the next element depends on the lowest level (which is usually an alternative set); (3) make a set of pairwise matrix comparison; and, (4) Use the priorities obtained from the comparison to consider priorities in the immediate level below them.

Population, Sample, Criteria

Population of this study is all lecturers of Faculty of Economics and Business, Brawijaya University which carry out "Tri Dharma Perguruan Tinggi" activities. The choice of the university sector in this study is based on a reason that the university is a service-based business sector with human resources as the main resource. This study was conducted on a sample basis. The sampling method is conducted in nonprobability sampling type by judgment sampling method which is a method that involves choices of the subject that has the most favorable place or the best position that provides the required information [20].

According to "Tri Dharma Perguruan Tinggi", the obligation of university as higher education institution, lecturer activities are research \& publication, education/teaching activity as academic activity and public or vocational services, including student-involved activity as non-academic activity with students. These activities become selected criteria for this study, because these activities require certain competence of all human resource of the university in enhancing the better quality and accreditation of the HEI. As for the alternatives are the costs for achieving competencies, including: (a) Training and workshop defines as the effort to increase technical performance in short term; (b) Self-development defines as the effort to develop self-potential and talent; and (3) Diploma as the effort to achieving competencies of academic and professional degree.

\section{Results}

In this research, the AHP method is applied in the decision-making system to determine the priority of the importance cost of human resource development valuation in a higher education institution. These criteria include (1) Education activity (Q1); (2) Research and publication activity (Q2); (3) Public and vocational service activity (Q3); and (4) Student-involved activity (Q4). Meanwhile, some alternatives used in this study consist of (1) Training and workshop (T); (2) Diploma and professional 
certification (D); and (3) Self-development (SD). These alternatives are used at this stage with consideration of the benefits received from the costs incurred to fund human resource development activities at the faculty level.

Data analysis by using the AHP method through some stages, which are described on the previous section. Based on input data from the questionnaires that distributed to all lecturers of faculty of economics and business, Brawijaya University, asking about their perceived value of selected criteria and alternatives in determining the value of human resource related to the higher education institution quality in the future. Before answering the research problem that have been identified, first step in AHP method is to compile the important score of selected criteria in a matrix pair shown in Table 4.1.

Table 1. The Importance Score of Selected Criteria Compiled in Matrix Forms of Pairs

\begin{tabular}{ccccc}
\hline Criteria & Q1 & Q2 & Q3 & Q4 \\
\hline Q1 & 1.0000 & 0.1429 & 5.0000 & 4.0000 \\
Q2 & 7.0000 & 1.0000 & 0.1538 & 0.1351 \\
Q3 & 0.2000 & 6.5000 & 1.0000 & 0.2941 \\
Q4 & 0.2500 & 7.4000 & 3.4000 & 1.0000 \\
\hline Total & 8.4500 & 15.0429 & 9.5538 & 5.4293 \\
\hline
\end{tabular}

Table 4.1 shows the calculation results of matrix pairs over the data criteria in this study, as well as the number of columns of each criterion which is subsequently used in calculating the weights of the selected criteria shown in Table 4.2.

Table 2. Calculation The Weights of Selected Criteria

\begin{tabular}{cccccc}
\hline & Q1 & Q2 & Q3 & Q4 & $\begin{array}{c}\text { weights of } \\
\text { selected criteria }\end{array}$ \\
\hline Q1 & 0.118 & 0.009 & 0.523 & 0.737 & 0.347 \\
Q2 & 0.828 & 0.066 & 0.016 & 0.025 & 0.234 \\
Q3 & 0.024 & 0.432 & 0.105 & 0.054 & 0.154 \\
Q4 & 0.030 & 0.492 & 0.356 & 0.184 & 0.265 \\
\hline & 1.000 & 1.000 & 1.000 & 1.000 & 1.000 \\
\hline
\end{tabular}

Based on Table 4.1 shows that the education activity (Q1) less important than research and publication activity $(\mathrm{Q} 2)$. After generating the weights of the selected criteria, the next step is to calculate the priority of each alternative. The priority values for each alternative are presented in the following Table 4.3

Table 3. The Value of Alternative Priorities for Selected Criteria (Q1)

\begin{tabular}{ccccc}
\hline Alternatives & $\mathrm{Q} 1$ & $\mathrm{Q} 2$ & $\mathrm{Q} 3$ & $\mathrm{Q} 4$ \\
\hline $\mathrm{T}$ & 0.005 & 70.000 & 0.003 & 30.000 \\
$\mathrm{D}$ & 0.010 & 40.000 & 0.010 & 20.000 \\
$\mathrm{SD}$ & 0.030 & 20.000 & 0.001 & 80.000 \\
\hline Total & 0.018 & 130.000 & 0.014 & 130.000 \\
\hline
\end{tabular}

When the calculation has been done by tricking of some multiply the matrix, global priorities of each alternative be obtained and presented at Table 4.4. In overall, diploma is a top priority to be capitalized as the cost of human resource development both in education, research \& publication, public services, and student activities. Diploma defines as effort of lecturer to achieving competencies of academic degree — by having doctoral education — and professional degree — by having professional certification like CPA, CMA, etc. Diploma cost is high because having degree is needed much money than training or self-development. Diploma cost post must be considered as asset for higher education institution.

Table 4. The Result of Priority Calculation of Each Alternative Based on Each Criterion

\begin{tabular}{ccc}
\hline & Scores & Priority Order \\
\hline $\mathrm{T}$ & 0.321 & 2 \\
$\mathrm{D}$ & 0.418 & 1
\end{tabular}




\begin{tabular}{lll} 
SD & 0.260 & 3 \\
\hline & 1.000 \\
\hline
\end{tabular}

\section{Discussion}

In the current era of globalization, the business world is beginning to experience a transition, where the transition leads to the business worldview of the importance of human resources within the company. This is inseparable from the development of technology and science developed by humans, so the most important in a company is not how much the value of machines or other physical assets, but the most important is the potential of human resources owned by a company. A company must maintain its competitive advantage in business competition, where physical assets are incapable of achieving that goal. Therefore, human resources are the one to play an important role in realizing the company's goals [8; 12; 27]

So far, the value of human resources is considered irrelevant to be capitalized as an asset. This is because the value complexity of human resources is not the same as the physical assets in a company. However, with the shifting of the business world paradigm, the value of human resources began to be considered as an added value for the company. The value of human resources as assets will become more relevant in the service industry, especially in educational institutions, where the prime mover in an educational institution, especially an institution of higher education is human resources and not physical assets such as the value of the building or the value of other physical facilities. The most significant expenditure of an institution of higher education comes from honoraria and other expenses related to the development of its human resources. So it also supports the importance of an institute of higher education to begin to conceptualize the valuation of the value of its human resources as an asset.

This study no longer finds out whether the value of human resources is relevant to a higher education institution. This study has entered into the stages of what costs are a priority in the higher education institution to be capitalized as human resource assets of the institution. It is based on the concept that personnel capability is one of the superior values in higher education institutions which can support the competitiveness of a university. Therefore, higher education institution in which the human resources are as its main asset, should no longer burden cost of human resource development as expenses but as assets that able to give economic benefit both in short and long term. The benefits that can be given from the potential of human resources in the higher education institutions are not only short-term economic benefits such as increasing the number of students each year, but they receive long-term benefits from human resource potential such as the branding value of higher education institutions. Therefore, the increase of student bodies may not only be achieved in short-term, but it can take place continuously as well as the quality of higher education institutions sustainably could be maintained.

The results show that the main priority that can be valued as an asset in each criterion is the cost of diploma (achieving professional and academic degree). This is because the diploma costs are not small. Also, diploma not only provides benefits for professional and academic development but also able to provide benefits to the development of institutions one of them in accreditation of higher education institutions. Where the data becomes, one of the requirements of graduation of study programs in accreditation is the availability of data on the potential of human resources. The importance of diploma (achieving professional and academic degree) for educators in higher education institutions began to realize the benefits. Because diploma (achieving professional and academic degree) can provide added value for an academician and it can increase the value of educational institutions in the eyes of society. Currently professional and academic degree is not only considered an additional degree for an academician in a higher education institution. Instead, it can improve the image of higher education institutions in the eyes of the public. For example, if lecturer has doctoral degree, they will be invited to do post-doctoral for country interest, besides if lecturer has professional degree like CPA (Certificate Public Accountant), they will be hired by government or corporate to become their consultant. This will provide direct economic benefits to the institution that is increasing public interest in higher education institutions and also establish relationship with various parties.

Diploma achievement can be interpreted as the value of a person's services which the human resource has the ability for competency development $[10 ; 12 ; 22]$ and it can improve specific knowledge, skills and experience that reflect the individual asset multiplier [22]. Diploma (achieving professional and academic degree) becomes the main priority to be accounted into the value of human resource assets, 
because the importance of academic and professional competence an educator in higher education institutions. The competence of lecturers is defined as a set of knowledge, skills, and behaviors that must be acquired, lived, mastered and realized by the lecturers in carrying out their professional duties. These competencies determine the quality of the implementation of Tridharma University as shown in the professional activities of lecturers. The result is supporting previous studies which reveal that humans have a human capital dimension which is the collective number of attributes, life experiences, knowledge, innovation, energy, and enthusiasm of a person choosing to work in their place of work $[7 ; 11 ; 17]$. Human capital refers to a combination of factors owned by each and the ability of the workforce collectively in a company [1]. These factors include knowledge, skills and technical skills, personal characteristics such as intelligence, energy, attitude, reliability, commitment, learning ability, including talent, imagination and creativity, to share information, participate in teams and focus on achieving organizational goals $[4 ; 13 ; 23]$. On a personal level, these organizations are full of talented, intelligent, and creative people at every level $[6 ; 22]$. Therefore, the potential of human resources in a company allows them to build their value internally.

The highest criteria for lecturer activities are doing research and publication. The result supports previous study that human capital especially number of researcher become top priority in the intellectual capital is for growth and Higher Education Institution development [16]. Total number of researcher and publication in Higher Education Institution (human capital indicators) becomes top priorities because these are component of academic intellectual capital. Improving academic intellectual capital especially human capital means improving academic performance in higher education institution.

\section{Conclusion}

Based on the results and discussion, it can be concluded: (1) As the result of AHP, Diploma (achieving professional and academic degree) cost is the most priority to develop competencies of human resources in higher education institution; (2) Improving human resource competencies can increase the value of lecturer, also increase economic and non-economic values for organization; (3) As the largest expenditure in higher education institution is the cost of human resource development for improving quality human resources, it should be capitalized into assets; and (4) research \& publication activity becomes highest criteria for lecturer activities. The result is also supporting previous studies for human capital dimension [7; 11; 17] owned by each workforce [1] for achieving organizational goals [4; 23]. Moreover, improving intellectual capital will also bring better academic performance in higher education institution [16].

As human resources in a company may provide benefits to investors, thus it would become an indicator of current organizational conditions and prospectus of organization performance in the future [15]. Improving the quality of human resources in higher education is the foundation for improving the quality of educational services.

This study used primary data of lecturers' response through closed questionnaire, asking respondents' perception of which cost that may contribute the value of the high education institution. As the result shows diploma cost as the priority of respondents' perception about the human capital valuation. There is some condition may affect respondent perception, such as the demand of higher education institution for having professional certification/degree. Moreover, the selected alternatives that used in further research may expand to other determined factors such as the regulation of higher education institution, other stakeholder's perception about human capital's value in the HEI.

\section{References}

[1]Abeysekera, I., \& Guthrie, J.: Human capital reporting in a developing nation. The British Accounting Review, Vol. 36, pp. 251-168 (2004)

[2]Auerbach, L. R., \& Sadan, S.: A stochastic model for human resources valuation. California Management Review Summer, Vol. 16, pp. 24 (1986)

[3]Avazzadehfath, F.: Decision-making based on human resource accounting information and its evaluation method. Asian Journal of Finance \& Accounting, Vol. 3(1) (2011)

[4]Benzoni, L., \& Chyruk, O.: The value and risk of human capital. Annual Review of Financial Economics, Vol. 7, pp. 179-200 (2015) 
[5]Board, I. A. S.: International Accounting Standard 38: Intangible Assets International Financial Reporting Standards. International Accounting Standards Board, London (1998)

[6]Bontis, N.: Assessing knowledge assets: A review of the models used to measure intellectual capital. International journal of management reviews, Vol. 3(1), pp. 41-60 (2001)

[7]Bullen, M. L., \& Kel-Ann, E.: Human resource accounting and international developments: Implications for measurement of human capital. Journal of International Business and Cultural Studies, Vol. 1(16) (2010)

[8]Burton-Jones, A., \& Spender, J.: The Oxford handbook of human capital. Oxford University Press, Oxford (2012)

[9]Carlucci, D., \& Schiuma, G.: Knowledge assets value creation map. Expert Systems with Applications, Vol. 32(3), pp. 814-821(2007)

[10]Flamholtz, E.: A model for human resource valuation: A stochastic process with service rewards. The Accounting Review, Vol. 46(2), pp. 253 (1971)

[11]Flamholtz, E.: Human Resource Accounting: Third Edition. Springer-Verlag, New York (2012)

[12]Flamholtz, E., \& Main, E. D.: Current issues, recent advancements, and future directions in human resource accounting. Journal of Human Resource Costing and Accounting, Vol. 4(1), pp. 11-12 (1999)

[13]Forman, E., \& Mary-Ann, S. Decision by Objectives. Retrieved from http://www.mdm.gwu.edu (2010)

[14]Fulmer, I. S., \& Ployhart, R. E.: Our Most Important Asset. Journal of Management, Vol. 40(1), pp. 161-192 (2014)

[15]Gillespie, J. F., Leininger, W. E., \& Kahalas, H.: A human resource planning and valuation model. Academy of Management Journal, Vol. 19(4), pp. 650-656 (1976)

[16 ]Golshahi, A., Estahbanati, F. K., Haghparast, A. A., \& Nou, Z. R. G. : Identifying And Ranking Indicators Of Intellectual Capital In Higher Educational Institutions From Perspective Of Faculty Members: A Case Study University Of S And B. Journal Of Scientific Research And Development, Vol. 2(3), pp. 169-176 (2015)

[17]Grimaldi, M., \& Rippa, P.: An AHP-based framework for selecting knowledge management tools to sustain innovation process. Knowledge and Process Management, Vol. 18(1), pp. 45-55 (2011)

[18]Kianto, A., Sáenz, J., \& Aramburu, N.: Knowledge-Based Human Resource Management Practices, Intellectual Capital and Innovation. Journal of Business Research, Vol. 81, pp. 11-20 (2017)

[19]Latifah, S.: Prinsip-Prinsip Dasar Analytical Hierarchy Process. Universitas Sumatra Utara, Medan (2005)

[20]Malhotra, N. K.: Marketing Research: An Applied Orientation (Global Ed.). Pearson, London (2019)

[21]Mayo, A.: The role of employee development in the growth of intellectual capital. Personnel Review, Vol. 29(4), pp. 521-533 (2000)

[22]Mayo, A.: The human value of the enterprise The Ultimate Resource Vol. 2, pp. 139-141 (2006)

[23]McCracken, M., McIvor, R., Treacy, R., \& Wall, T.: A study of human capital reporting in the United Kingdom. Accounting Forum, Vol. 42(1), pp. 130-141 (2018)

[24]Ngai, E. W. T., \& Chan, E. W. C.: Evaluation of knowledge management tools using AHP. Expert Systems with Applications, Vol. 29(4), pp. 889-899 (2005)

[25]Ozkan, N., Cakan, S., \& Kayacan, M.: Intellectual Capital And Financial Performance: A Study Of The Turkish Banking Sector. Borsa Istanbul Review, Vol. 17(3), pp. 190-198 (2017)

[26]Parker, L. D., Ferris, K. R., \& Otley, D. T.: Accounting For the Human Factor. Prentice Hall, New York (1989)

[27]Pastor, D., Glova, J., Lipták, F., \& Kováč, V.: Intangibles and methods for their valuation in financial terms: Literature review. Intangible Capital, Vol. 13(2), pp. 387 (2017)

[28]Saaty, T. L. \& Vargas, L.G.: Models, Methods, Concepts and Applications of the Analytic Hierarchy Process, $2^{\text {nd }}$ Edition. Springer, New York (2012)

[29]Sarwoko, I. Keterkaitan strategi manajemen sumber daya manusia dengan akuntansi sumber daya manusia. Universitas Padjadjaran, Bandung (2009)

[30]Secundo, G., Dumay, J., Schiuma, G., \& Passiante, G.: Managing intellectual capital through a collective intelligence approach: an integrated framework for universities. Journal of Intellectual Capital, Vol. 17(2), pp. 298-319 (2016) 
[31]Undang-Undang No. 12 Tahun 2012 Tentang Perguruan Tinggi. Kementerian Pendidikan dan Kebudayaan, Jakarta (2012)

[32]Undang-Undang No. 14 Tahun 2005 Tentang Guru dan Dosen. Departemen Pendidikan Nasional, Jakarta (2005) 